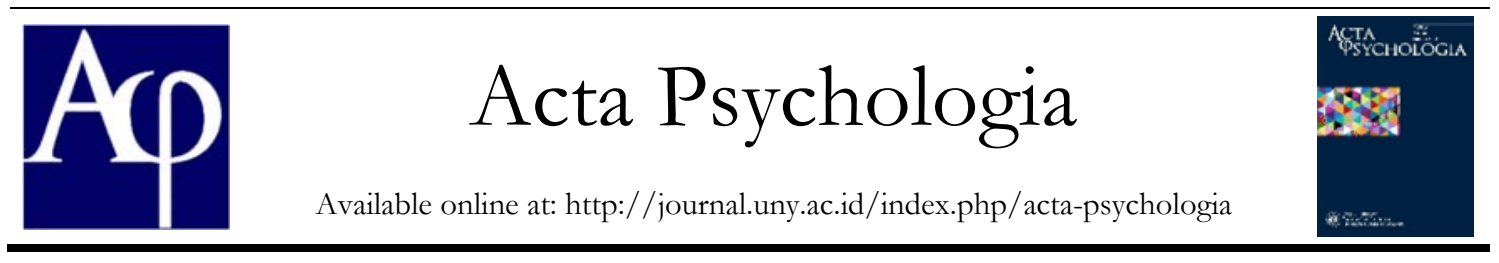

\title{
Pengaruh Komitmen Organisasi terhadap Turnover Intention Karyawan Generasi Milenial pada Perusahaan The Rich Jogja Hotel
}

\author{
Ayuza Amalia \\ Jurusan Psikologi, Universitas Negeri Yogyakarta; Jl. Colombo No. 1 Sleman Yogyakarta, 55281 \\ Ayuzaa98@gmail.com
}

\begin{abstract}
Abstrak
Penelitian ini bertujuan untuk mengetahui pengaruh komitmen organisasi terhadap turnover intention pada karyawan generasi milenial di The Rich Jogja Hotel. Penelitian menggunakan pendekatan kuantitatif dan termasuk penelitian ex-post facto. Subjek yang terlibat berjumlah 102 karyawan generasi milenial. Instrumen penelitian yang digunakan adalah skala turnover intention dan komitmen organisasi. Hasil seleksi item menunjukkan bahwa angka korelasi item total berkisar antara 0,527-0,779. Reliabilitas menggunakan koefisien reliabilitas Alpha Cronbach, dan seluruhnya dinyatakan reliabel. Berdasarkan hasil analisis regresi berganda, ditemukan bahwa: (1) komitmen organisasi berpengaruh negatif terhadap turnover intention, dengan nilai $F$ hitung sebesar $35,474(p<0,05)$ dan sumbangan $\mathrm{R}^{2}=52,1 \%$, (2) komitmen afektif berpengaruh negatif terhadap turnover intention, dengan nilai koefisien regresi 0,928 , nilai t hitung $-3,894(\mathrm{p}<0,05)$, dan sumbangan $\mathrm{R}^{2}=21,3 \%$, (3) komitmen normatif berpengaruh negatif terhadap turnover intention, dengan nilai koefisien regresi $-0,703$, nilai t hitung $-2,259(\mathrm{p}<0,05)$, dan sumbangan $\mathrm{R}^{2}=9,3 \%$, (4) komitmen keberlanjutan berpengaruh negatif terhadap turnover intention, dengan nilai koefisien regresi $-0,964$, nilai t hitung $-4,186(\mathrm{p}<0,05)$, dan sumbangan $\mathrm{R}^{2}=21,5 \%$. Kesimpulan dari penelitian ini bahwa komitmen organisasi (komitmen afektif, komitmen normatif, dan komitmen keberlanjutan) berpengaruh negatif terhadap turnover intention pada karyawan generasi milenial di The Rich Jogja Hotel.
\end{abstract}

Kata Kunci: komitmen organisasi, turnover intention, generasi milenial

\begin{abstract}
This study aims to determine the effect of organizational commitment on turnover intentions on millennial generation employees at The Rich Jogja Hotel. Research uses a quantitative approach and includes ex-post facto research. The subjects involved were 102 millennial generation employees. The research instrument used was a psychological scale of turnover intention and organizational commitment. The item selection results show that the total item correlation number ranges from 0.527 to 0.779 . Reliability uses the Cronbach Alpha reliability coefficient, and all are declared reliable. Based on the results of the multiple regression analysis, it was found that: (1) organizational commitment had a negative effect on turnover intentions, with a calculated $\mathrm{F}$ value of $35.474(\mathrm{p}$ $<0.05$ ) and a contribution of $\mathrm{R}^{2}=52.1 \%$, (2) affective commitment had a negative effect on turnover intention, with a regression coefficient of -0.928 , a calculated $t$ value of $3.889(\mathrm{p}<0.05)$, and a contribution of $\mathrm{R}^{2}=21.3 \%$, (3) normative commitment negatively affects turnover intention, with a regression coefficient of -0.703 , $t$ value 2,259 ( $\mathrm{p}<0.05$ ), and contribution $\mathrm{R}^{2}=9.3 \%$, (4) sustainability commitment has a negative effect on turnover intention, with a regression coefficient value of -0.964 , $\mathrm{t}$-value of $-4.186(\mathrm{p}<0,05)$, and the contribution $\mathrm{R}^{2}=$ $21.5 \%$. The conclusion of this study is that organizational commitment (affective commitment, normative commitment and sustainability commitment) negatively affects turnover intentions of millennial generation employees at The Rich Jogja Hotel.
\end{abstract}

Keywords: organizational commitment, turnover intention, millennial generation 


\section{Pendahuluan}

Pada era globalisasi angkatan kerja didominasi oleh generasi milenial. Buku profil generasi milenial yang dirilis oleh BPS (Badan Pusat Statistik), menyatakan bahwa generasi milenial sedang mendominasi angkatan kerja. Hal tersebut dapat dikaitkan oleh penjelasan dari Ball \& Gotsill bahwa generasi milenial merupakan mereka yang lahir pada tahun 1983-1997, dengan usia saat ini 22-36 tahun (Nindyati, 2017:63).

Survei yang sebelumnya telah dilakukan menyebutkan bahwa ideal lama bekerja bagi generasi milenial yaitu hanya dua sampai tiga tahun saja, lalu melakukan turnover (Folia,2019). Penelitian sebelumnya menyebutkan terdapat faktor determinan yang mampu mempengaruhi turnover intention pada karyawan yaitu, kepuasan kerja dan komitmen organisasi (Mobley, dkk., 1978:411). Selanjutnya ditemukan pula bahwa komitmen organisasi merupakan salah satu prediktor dalam mengukur turnover intention karyawan dalam perusahaan (Satwari, dkk., 2016:179).

Hasil dari pra penelitian yang sebelumnya dilakukan pada perusahaan The Rich Jogja Hotel menyatakan bahwa terdapat kecenderungan pengaruh positif antara komitmen organisasi dan turnover intention yang dimiliki oleh karyawan. hal tersebut berbeda dengan penelitian sebelumnya yang dilakukan oleh Yulianti, dkk. (2019:6), Kharismawati dan Dewi (2016:1394), serta Satriya dan Hadi (2018:5) yang menyatakan bahwa komitmen organisasi berpengaruh negatif terhadap turnover intention. Oleh karena itu, penelitian ini dilakukan untuk mengulas kembali pengaruh komitmen organisasi terhadap turnover intention terhadap karyawan generasi milenial di perusahaan The Rich Jogja Hotel.

Peneliti memberi batasan terhadap masalah yang telah diidentifikasi yaitu pada kecenderungan meningkatnya turnover intention pada karyawan generasi milenial
The Rich Jogja Hotel. Sementara, terdapat kecenderungan yang rendah pada komitmen organisasi karyawan generasi milenial The Rich Jogja Hotel. Oleh karena itu penelitian ini bertujuan untuk mengetahui pengaruh dari komitmen organisasi terhadap turnover intention pada karyawan generasi milenial di lingkungan perhotelan (The Rich Jogja Hotel).

\section{Metode Penelitian}

Penelitian ini merupakan penelitian kuantitatif dan penelitian ex-post facto.

Penelitian ini dilaksanakan di perusahaan The Rich Jogja Hotel. Berlokasi di Jalan Magelang, KM.6, No. 18, Kutu Patran, Sinduadi, Mlati, Kabupaten Sleman, Daerah Istimewa Yogyakarta. Penelitian dilaksanakan selama empat bulan. Dimulai dari bulan Agustus sampai dengan bulan Desember 2019.

Subjek pada penelitian ini yaitu karyawan generasi milenial pada The Rich Jogja Hotel. Populasi penelitian ini berjumlah 152 karyawan, dengan perhitungan pengambilan sampel menggunakan rumus Slovin. Didapatkan sampel sebanyak 110 karyawan. Teknik pengambilan sampel dalam penelitian ini menggunakan accidental sampling. Akan tetapi, melalui pengambilan sampel yang telah dilakukan, hanya 102 karyawan saja yang memenuhi kriteria dan dapat dianalisis datanya.

Penelitian ini dilakukan dengan cara mengumpulkan data melalui skala psikologis komitmen organisasi dan turnover intention. Skala psikologis diberikan kepada karyawan generasi milenial sesuai dengan teknik accidental sampling, yaitu dengan menyebarkan secara eksidental karyawan generasi milenial yang kebetulan dijumpai oleh HRD (Human Resource Department) The Rich Jogja Hotel. Kemudian setelah data dikumpulkan maka data dapat dianalisis menggunakan bantuan program Software SPSS 20.0. Sebelum dilakukan uji hipotesis menggunakan analisis regresi berganda, 
data harus melalui uji prasyarat analisis. Uji prasyarat analisis diantaranya yaitu, uji normalitas, uji linieritas, uji multikolinieritas, uji autokorelasi, dan uji heteroskedastisitas. Setelah dilakukan seluruhnya, maka dapat dilakukan pembahasan mengenai hasil analisis penelitian ini.

Data diperoleh langsung dari subjek penelitian. Data tersebut diperoleh melalui 2 instrumen penelitian yang disebar peneliti kepada 102 karyawan generasi milenial di The Rich Jogja Hotel. Adapun instrumen yang digunakan yakni skala psikologis turnover intention dan skala psikologis komitmen organisasi. Skala tersebut berbentuk skala Likert, yang dimodifikasi melalui skala turnover intention oleh Mobley, dkk. (1978:411) dan skala komitmen organisasi mengacu pada skala dari Meyer, dkk. (1993:544). Skala psikologis turnover intention terdiri atas 19 item, sedangkan skala psikologis komitmen organisasi terdiri atas 24 item. Masing-masing subjek mengisi itemitem tersebut (dalam kurun waktu kurang lebih satu minggu), kemudian skala tersebut dikembalikan ke peneliti untuk diolah dan dianalisis.

Teknik analisis data penelitian ini adalah analisis deskriptif dan uji hipotesis. Analisis deskriptif meliputi analisis deskriptif karakteristik subjek dan analisis deksriptif kategori variabel. Uji hipotesis dilakukan melalui uji analisis regresi linier berganda, dengan bantuan Software SPSS 20.0. Uji hipotesis sebelumnya harus melalui uji prasyarat analisis terlebih dahulu. Uji prasyarat analisis meliputi uji normalitas, uji linieritas, uji multikolinieritas, uji autokorelasi, dan uji heteroskedastisitas. Selanjutnya, hasil yang didapatkan dapat dianalisis dalam pembahasan.

\section{Hasil Penelitian dan Pembahasan}

Penelitian ini melibatkan 102 subjek penelitian karyawan generasi milenial, lakilaki sebanyak 89 karyawan atau sebesar
$81 \%$. Selain itu memiliki pendidikan terakhir SMA/SMK atau yang sederajat, yaitu sebanyak 89 karyawan atau sebesar 81\%. Mayoritas lama kerja kurang dari dua tahun sebanyak 62 karyawan atau sebesar $56 \%$.

Mayoritas karyawan pada penelitian ini berada pada Departemen Front Desk Officer sebanyak 38 karyawan atau sebesar $35 \%$. Oleh karena itu, terbukti bahwa penelitian ini melibatkan subjek penelitian karyawan generasi milenial.

Analisis deskriptif menghasilkan kategorisasi sedang pada turnover intention, yaitu sebesar 39,2\%, diperoleh dari 40 karyawan. Hasil kategorisasi pada komitmen organisasi memiliki tingkat sangat tinggi, yaitu sebesar $66 \%$ yang diperoleh dari 67 karyawan.

Tabel 1. Rangkuman Hasil Analisis Regresi Berganda.

\begin{tabular}{|c|c|c|c|c|}
\hline Variabel & $\begin{array}{c}\text { Koefisi } \\
\text { en } \\
\text { Regresi }\end{array}$ & $\mathrm{t}$ & $\mathrm{p}$ & $\begin{array}{l}\text { Contri } \\
\text { bu- } \\
\text { tion }\end{array}$ \\
\hline Konstanta & 128,254 & & & \\
\hline $\begin{array}{l}\text { Komitmen } \\
\text { Afektif }\end{array}$ & $-0,928$ & $-3,894$ & 0,00 & $21,3 \%$ \\
\hline $\begin{array}{l}\text { Komitmen } \\
\text { Normatif }\end{array}$ & $-0,703$ & $-2,259$ & $\begin{array}{l}0,02 \\
6\end{array}$ & $9,3 \%$ \\
\hline $\begin{array}{l}\text { Komitmen } \\
\text { Keberlanjut } \\
\text { an }\end{array}$ & $-0,964$ & $-4,186$ & $\begin{array}{l}0,00 \\
0\end{array}$ & $21,5 \%$ \\
\hline $\begin{array}{l}\text { Komitmen } \\
\text { Organiasi }\end{array}$ & & & & $52,1 \%$ \\
\hline F hitung & 35,474 & & $\begin{array}{l}0,00 \\
0\end{array}$ & \\
\hline $\mathrm{R}$ & 0,722 & & & \\
\hline $\mathrm{R}$ Square & 0,521 & & & \\
\hline
\end{tabular}

Berdasarkan rangkuman hasil analisis regresi, maka diketahui bahwa komitmen afektif, komitmen normatif, dan komitmen keberlanjutan secara simultan (bersamasama) berpengaruh negatif terhadap turnover intention. Hal tesebut dibuktikan oleh nilai signifikansi $\mathrm{F}$ hitung sebesar $0,000 \quad(p<0,05)$. Selanjutnya, sumbangan secara simultan dilihat melalui hasil $\mathrm{R}$ Square $\left(\mathrm{R}^{2}\right)$ sebesar $52,1 \%$. 
Melalui keterkaitan dengan hipotesis penelitian yang diajukan oleh peneliti, penelitian ini memenuhi keempat hipotesis. Hipotesis pertama mengajukan adanya pengaruh dari komitmen organisasi terhadap turnover intention pada karyawan generasi milenial di The Rich Jogja Hotel, terbukti melalui hasil uji analisis regresi linier berganda yang telah dilakukan. Komitmen organisasi terbukti berpengaruh negatif terhadap turnover intention karyawan generasi milenial pada The Rich Jogja Hotel sebesar $52,1 \%$. Hal tersebut berarti jika karyawan generasi milenial pada The Rich Jogja Hotel yang memiliki tingkat komitmen organisasi (secara simultan) tinggi, maka akan memiliki ketertarikan emosional yang kuat terhadap perusahaan, memiliki rasa tanggungjawab moral yang besar terhadap perusahaan, serta memiliki ketergantungan yang tinggi terhadap nilai ekonomi pada perusahaan. Sikap-sikap yang biasa ditunjukkan yaitu merasa nyaman berada pada perusahaan, merasa memiliki tanggungjawab yang besar terhadap pekerjaannya, dan juga memiliki ketergantungan yang tinggi pada penghasilan yang diberikan oleh perusahaan.

Hipotesis kedua mengajukan adanya pengaruh dari komitmen afektif terhadap turnover intention pada karyawan generasi milenial di The Rich Jogja Hotel, terbukti melalui hasil uji analisis regresi linier berganda yang telah dilakukan. Berdasarkan rangkuman hasil analisis regresi berganda, diketahui nilai t hitung sebesar -3,894 dan koefisien regresi sebesar 0,928 dengan signifikansi $0,000(\mathrm{p}<0,05)$. Hasil tersebut menunjukkan bahwa komitmen afektif berpengaruh negatif terhadap turnover intention. Sedangkan besaran pengaruh atau kontribusinya yatu sebesar $21,3 \%$, dan sisanya sebesar $78,7 \%$ merupakan unsur-unsru lain yang tidak diteliti dalam penelitian ini. Hal tersebut berarti jika karyawan generasi milenial pada The Rich Jogja Hotel yang memiliki komitmen afektif tinggi, maka akan memiliki ketertarikan emosional yang kuat terhadap perusahaan, serta berupaya untuk terus bekerja pada perusahaan atas dasar keyakinan nilai terhadap perusahaan tersebut. Sikap-sikap yang biasa ditunjukkan yaitu merasa nyaman berada pada perusahaan, merasa bangga telah bekerja pada perusahaan, dan juga memiliki perasaan bahagia saat merasa bekerja dengan atmosfer kekeluargaan di perusahaan.

Selanjutnya hipotesis ketiga yang diajukan yaitu, adanya pengaruh dari komitmen normatif terhadap turnover intention pada karyawan generasi milenial di The Rich Jogja Hotel. Hipotesis tersebut sepenuhnya diterima karena hasil uji regresi linier berganda diketahui nilai $t$ hitung sebesar -2,259 dan koefisien regresi sebesar $-0,703$ dengan signifikansi $0,000(p<0,05)$. Besaran sumbangan terhadap variabel turnover intention sebesar 9,3\%, lalu sisanya sebesar $90,7 \%$ merupakan unsur-unsur yang tidak diteliti dalam penelitian ini. Hal tersebut memiliki arti adanya pengaruh yang dihasilkan oleh komitmen normatif terhadap turnover intention. Serta nilai negatif pada koefisien regresi menjelaskan bahwa pengaruh yang dihasilkan yaitu pengaruh negatif. Hal tersebut berarti jika karyawan generasi milenial pada The Rich Jogja Hotel yang memiliki komitmen normatif tinggi akan mampu menjalani kewajiban yang ditanggungjawabkan dengan baik, serta berupaya untuk terus bekerja pada perusahaan atas dasar alasan moral terhadap perusahaan. Sikap-sikap yang biasa ditunjukkan yaitu merasa bahwa loyalitas pada perusahaan merupakan hal yang penting, merasa bahwa dirinya memegang peranan penting pada perusahaan, dan juga merasa memiliki tanggung jawab yang besar untuk terus menjalankan kewajibannya di perusahaan.

Selain itu hipotesis keempat yang diajukan oleh penelitian ini bahwa adanya pengaruh dari komitmen keberlanjutan terhadap turnover intention pada karyawan generasi milenial di The Rich Jogja Hotel, 
diterima. Menurut hasil uji analisis regresi linier berganda diketahui nilai $\mathrm{t}$ hitung sebesar -4,186 dan koefisien regresi sebesar $-0,964$ dengan signifikansi $0,000(\mathrm{p}<0,05)$.

Besaran sumbangan terhadap variabel turnover intention sebesar $21,5 \%$, lalu sisanya sebesar 78,5 merupakan unsur-unsur yang tidak diteliti dalam penelitian ini. Hal tersebut berarti jika komitmen keberlanjutan yang dimiliki karyawan generasi milenial pada The Rich Jogja Hotel tinggi, maka dapat diliat berdasarkan nilai kebermanfaatan ekonominya (upah, jabatan, fasilitas atau bonus) yang diperolehnya. Sikap-sikap yang biasa ditunjukkan yaitu merasa bahwa hanya perusahaan ini yang mampu memenuhi kebutuhan, merasa bahwa perusahaan ini satusatunya sumber pendapatan, dan juga dapat merasa bahwa perusahaan ini menjadi sumber relasi baik yang tidak dapat ditinggalkan. Melalui penjelasan di atas maka dapat disimpulkan bahwa hal tersebut berarti keempat hipotesis yang diajukan pada penelitian ini seluruhnya diterima.

Penelitian ini membuktikan bahwa sebagian besar karyawan pria berusia 20-25 tahun yang bekerja pada The Rich Jogja Hotel memiliki masa kerja kurang dari dua tahun, dengan pendidikan terakhir SMA/SMK sederajat. Melalui hal tersebut merujuk pada masa ideal bekerja karyawan generasi milenial yang hanya satu sampai dua tahun. Terbukti dengan hasil penelitian ini, dimana usia 20-25 tahun yang menjadi usia generasi milenial paling banyak mengisi skala psikologi penelitian ini. Keseluruhan hasil yang diperoleh jika dianalisis dengan tahapan proses perkembangan manusia.

Pada psikologi perkembangan, karyawan generasi milenial yang mayoritas pada penelitian ini berusia 20-25 tahun masuk pada masa perkembangan dewasa awal (early adulthood). Baltes dan Smith (dalam Santrock, 2011:19) menyatakan bahwa masa dewasa menengah merupakan tahap untuk memperluas keterlibatan pribadi, sosial, dan tanggung jawab serta untuk meraih dan membina kepuasan karirnya. Oleh karena itu, keinginan dari karyawan generasi milenial untuk melakukan turnover intention dengan tujuan mengembangkan karirnya adalah hal yang sewajarnya dalam masa perkembangan. Akan tetapi, para karyawan generasi milenial tersebut juga terbelenggu oleh kenyataan akan hubungan yang telah terbangun dengan lekat dan membentuk sebuah komitmen organisasi pada karyawan generasi milenial. Hal tersebut dapat dijelaskan melalui tahap psikososial oleh Erikson (dalam Santrock, 2011:27) bahwa pada tahap dewasa awal individu akan membentuk persahabatan yang sehat dan relasi yang akrab dengan orang lain, sehingga dapat dianalisis bahwa karyawan generasi milenial telah membentuk tahapan tersebut.

Pada perspektif perilaku organisasi, Robbins (2006:279) menjelaskan bahwa semua perusahaan mempunyai budaya yang dapat memberi pengaruh yang bermakna terhadap sikap dan perilaku karyawan. Analisis terhadap hasil dari penelitian ini yaitu melalui bagaimana perusahaan The Rich Jogja Hotel mampu membangun atmosfer kekeluargaan dan budaya gotong royong yang kuat, sehingga karyawan generasi milenial memiliki tingkat komitmen organisasi 52,1\%. Dengan demikian, dapat komitmen organisasi (komitmen afektif, komitmen normatif, dan komitmen keberlanjutan) dapat memprediksi serta memberi pengaruh negatif pada turnover intention karyawan generasi milenial The Rich Jogja Hotel.

\section{Simpulan dan Saran}

Hasil analisis yang telah dilakukan membuktikan bahwa komitmen organisasi secara bersama-sama memberikan pengaruh negatif terhadap turnover intention karyawan generasi milenial The Rich Jogja Hotel. Serta komponen-komponen komitmen organisasi yang terdiri dari 
komitmen afektif, komitmen normatif, dan komitmen keberlanjutan, masing-masing secara mandiri memberikan pengaruh negatif terhadap turnover intention karyawan generasi milenial di The Rich Jogja Hotel. Melalui hasil pembahasan yang telah dilakukan maka: 1) Terbukti adanya pengaruh negatif dari komitmen organisasi terhadap turnover intention pada karyawan generasi milenial di The Rich Jogja Hotel. 2) Terbukti adanya pengaruh negatif dari komitmen afektif terhadap turnover intention pada karyawan generasi milenial di The Rich Jogja Hotel. 3) Terbukti adanya pengaruh negatif dari komitmen normatif terhadap turnover intention pada karyawan generasi milenial di The Rich Jogja Hotel. 4) Terbukti adanya pengaruh negatif dari komitmen keberlanjutan terhadap turnover intention pada karyawan generasi milenial di The Rich Jogja Hotel.

Dengan demikian, dapat disimpulkan bahwa apabila komitmen organisasi (komitmen afektif, komitmen normatif, dan komitmen keberlanjutan) yang dimiliki karyawan generasi milenial pada The Rich Jogja Hotel tinggi, maka dapat diprediksi bahwa turnover intention karyawan generasi milenial pada The Rich Jogja Hotel cenderung rendah. Begitupun sebaliknya.

Berdasarkan hasil penelitian, saran kepada perusahaan The Rich Jogja Hotel yaitu meliputi strategi dalam mempertahankan tingkat komitmen organisasi, agar dapat menurunkan turnover intention karyawan generasi milenial. Saran mengenai hal-hal yang dapat dilakukan yaitu dengan terus mengadakan staff committe agar dapat terus memupuk rasa nyaman antar sesama karyawan, ataupun kepada perusahaan karena telah mewadahi hobi karyawan. Selain itu, mempertahankan budaya organisasi yang telah dibentuk diantaranya yaitu iklim kekeluargaan dan gotong-royong dalam menyelesaikan pekerjaan. Selanjutnya dalam mengembangkan keahlian karyawan maka perusahaan dapat terus megadakan training setiap bulannya, serta terus mengadakan staff gathering dalam rangka penyampaian informasi terbaru mengenai perusahaan kepada seluruh karyawan.

Melalui hasil dari penelitian ini maka disarankan kepada karyawan generasi milenial dengan rentang usia 20-25 tahun dengan masa kerja kurang dari dua tahun, untuk lebih meningkatkan komitmen organisasi (komitmen afektif, komitmen normatif, dan komitmen keberlanjutan). Hal yang dapat dilakukan yaitu terus melibatkan diri dengan kegiatan-kegiatan di perusahaan. Selain itu, terus meningkatkan interaksi antar rekan kerja juga baik dalam meningkatkan relasi dunia kerja. Hal-hal tersebut diharapkan dapat menurunkan resiko terjadinya turnover intention pada perusahaan

Bagi penelitian yang tertarik melakukan penelitian ini diharapkan untuk mengobservasi dan mengeksplorasi lebih jauh permasalahan- permasalahan yang terdapat pada The Rich Jogja Hotel. Dengan demikian, diharapkan peneliti selanjutnya untuk dapat memperbaiki keterbatasan yang terjadi.

Berdasarkan hasil penelitian, diharapkan peneliti selanjutnya dapat mengembangkan penelitian ini dengan meneliti lebih luas lagi terkait faktorfaktor lain (kepribadian, sikap, motivasi, dan lain sebagainya) yang dapat mempengaruhi tinggi atau rendah komitmen organisasi dan turnover intention pada karyawan generasi milenial di The Rich Jogja Hotel.

\section{Daftar Pustaka}

Alsa, Asmadi. (2007). Pendekatan Kualitatif dan Kuantitatif serta Kombinasinya dalam Penelitian Psikologi. Yogyakarta: Pustaka Belajar.

Arikunto, Suharsimi. (2013). Prosedur Penelitian: Suatu Pendekatan Praktik. Jakarta: Rineka Cipta.

Azwar, Saifuddin. (2011). Penyusunan skala psikologis (Edisi 2). Yogyakarta: Pustaka Pelajar. 
Azwar, Saifuddin. (2016). Penyusunan Skala Psikologi. Yogyakarta: Pustaka Pelajar.

Biantoro, Linda Chandra. Sihombing, Ranto P. (2012). Pengaruh Komitmen Organisasi Terhadap Turnover Intention Melalui Kepuasan Kerja Dengan Budaya Organisasi Sebagai Variabel Anteseden. Universitas Katolik Soegijapranata Semarang. Jurnal Akuntansi Bisnis, 11(21), 62, 6194.

Folia, Rosa. (2019). IMR 2019: 11 Alasan Mengapa Millennial Mudah Pindah Kerja. IDN Times. Diakses tanggal 10 September 2019, dari https://www.idntimes.com/news/i ndonesia/rosa-folia/imr-201911alasan-mengapa-millennialmudahpindah-kerja/full.

Ghozali, Imam. (2016). Aplikasi Analisis Multivariate Dengan Program IBM. SPSS 23. Semarang: Badan Penerbit Universitas Diponegoro.

Halimsetiono, Elita. (2014). Peningkatan Komitmen Organisasi untuk Menurunkan Angka Turnover Karyawan. Universitas Airlangga. Jurnal Kesehatan Masyarakat Nasional, 8(8), 339345.

Hom, Peter W. Griffeth, Rodger W. \& Sellaro, C. Louise. (1984). The Validity of Mobley's (1977) Model of Employee Turnover. Kent State University. Organizational Behavior And Human Performance, 34(_), 141174.

Ibo, Ahmad. (2017). Riset: Tingkat Kesetiaan Karyawan Generasi Milenial Paling Rendah. Liputan6. Diakses 15 September 2019, dari https://www.liputan6.com/lifestyl e/ $\mathrm{read} / 2854466 /$ risettingkatkesetiaan-karyawangenerasimilenial-paling-rendah.
Ismail, M., Rahim, A. N., Hou Lee, K., \& Tahir, N. F. (2016). Cultural Values and Career Goal of Gen-X and Gen$Y$ Employees: Evidence from Selected Malaysia Companies. Organizations and Markets in Emerging Economies, 7( 2), 43 - 64.

Kharismawati, Dewa Ayu Putu. Dewi, I Gusti Ayu Manuati. (2016). Pengaruh Komitmen Organisasional, Dukungan Sosial, Dan Iklim Etika Terhadap Turnover Intention. Universitas Udayana. E-Jurnal Manajemen Unud, 5(2), 1368-1398.

Kratz, H. (2013). Maximizing millennials: The who, how, and why of managing gen $Y$. Diakses pada 3 Maret 2019, dari http://onlinemba.unc.edu/mbaatunc-blog/geny-in-theworkplace/.

Melizawati. (2015). Pengaruh Komitmen Organisasi Terhadap Kinerja Karyawan (Studi Kasus Pada PT.INDOTIRTA ABADI). Jurnal Akuntansi, 1(1), 15-16.

Meyer, John P. \& Allen, Natalie J. (1991). A Three-Component Conseptualization of Organizational Commitment. University of Western Ontario. Human Resource Management Review, 1(1), 61-89.

Meyer, John P. Allen, Natalie J. \& Smith, Catherine A. (1993). Commitmentt Organizations and Occupations: Extension and Test of a ThreeComponent Conceptualization. University of Western Ontario. Journal of Applied Psychology, 78(4), 538551.

Meydiana, Evita. Prasetya, Arik. Sulistyo, Cahyo Widyo. (2018). Analisis Faktor - Faktor yang Mempengaruhi Turnover Intention Pada Karyawan Generasi X Dan Generasi Y (Studi Pada Karyawan Pt Abc Sidoarjo). Univeristas Brawijaya. Jurnal Administrasi Bisnis (JAB), 61(3), 116124. 
Mobley, William H., Horner, Stanley O., Hollingsworth, A. T. (1978). An Evaluation of Percursors of Hospital Employee Turnover. University of South Carolina. Journal of Applied Psychology, 63(4), 408-414.

Mobley, W. H. (1986). Pergantian Karyawan: Sebab Akibat dan Pengendaliannya. Jakarta: PT Pustaka Binaman Pressindo.

Michaels, Charles E. \& Spector, Paul E. (1982). Causes of Employee Turnover: A Test of the Mobley, Griffeth, Hand and Meglino Model. Journal of Applied Psychology. University of South Florifa, 67(1), 53-59.

Nindyati, Ayu Dwi. (2017). Pemaknaan Loyalitas Karyawan Pada Generasi X dan Generasi Y (Studi Pada Karyawan Di Indonesia). Journal of Psychological Science and Profesion (IPSP), 1(1), 60-68.

Noor, J. (2011). Metodologi Penelitian: Skripsi, Tesis, Disertasi, dan Karya Imiah. Jakarta: Kencana.

Nurhasan, Rohimat. (2017). Kepuasan Kerja dan Loyalitas Generasi-Y. Jurnal Wacana Ekonomi, 17(1), 13-23.

Nydia, Yetta Tri. (2012). Peningkatan Komitmen Organisasi untuk Menurunkan Angka Turnover Karyawan. Jurnal Skripsi, 1(1), 10, 98.

Puteh, F., Kaliannan, M., \& Alam, N. (2015). Assessing Gen Y Impact on Organizational Performance: An Analysis from Top Management Perspective. Journal of Administrative Science, 12(1), 47 - 59.

Rachmah, Annisa Noviani. (2017). Pengaruh Komitmen Organisasi, Kepuasan Kerja Dan Budaya Organisasi Terhadap Turnover Intention Pada Karyawan Hotel Mutiara Merdeka Pekanbaru. Universitas Riau. Jurnal of Management (Fekon), 4(1), 60-71.
Retnawati, Heri. (2016). Analisis Kuantitatif Instrumen Penelitian (Panduan Peneliti, Mahasiswa, Dan Psikometrian). Yogyakarta: Parama Publishing, 1(1), 17, 85.

Ridlo, Ilham Akhsanu. (2012). Turnover Karyawan: Kajian Literatur. Surabaya: PHMovement Publication.

Robbins, Stephen. P. (2006). Perilaku organisasi. Edisi Kesepuluh. Jakarta: PT Indeks.

Santrock, John W. (2011). Pekembangan Masa Hidup. Edisi Ketigabelas, Jilid 1. Jakarta: PT. Gelora Aksara Pratama.

Santrock, John W. (2011). Pekembangan Masa Hidup. Edisi Ketigabelas, Jilid 2. PT. Gelora Aksara Pratama.

Sappaile, B.I. (2010). Konsep Penelitian Ex-Post Facto. Jurnal Pendidikan Matematika, 1(2), 105-113.

Satriya, M Galuh Ramadhan. Hadi, Cholichul. (2018). Pengaruh Komitmen Organisasi Terhadap Intensi Turnover pada Karyawan PT. SMB. Universitas Airlangga. Jurnal Psikologi Universitas Airlangga, 1(1), 1-13.

Satwari, Titis. Musadieq, Mochammad Al. Afrianty, Tri Wulida. (2016). Pengaruh Komitmen Organisasional Terhadap Turnover Intention (Survei pada Karyawan Hotel SwissBelinn Malang). Universitas Brawijaya. Jurnal Administrasi Bisnis (JAB), 40(2), 177-186.

Setiawati, Farida Agus. (2017). Statistika Terapan. Yogyakarta: Parama Publishing.

Sugiyono. (2001). Metode Penelitian Pendidikan. Bandung: Alfabeta.

Sugiyono. (2011). Metode Penelitian Kuantitatif, Kualitatif dan RひD. Bandung: Afabeta. 
Susilo, Jimmy. Satrya, I Gusti Bagus Honor. (2019). Pengaruh

Kepuasan Kerja Terhadap Turnover Intention yang Dimediasi oleh Komitmen Organisasional Karyawan Kontrak. Universitas Udayana. Jurnal Manajemen, 8(6), 37003729.

Widhiarso, W. (2010). Konstrak

Psikologis. Diakses pada 21 Juni 2019, dari

http://wahyupsy.blog.ugm.ac.id/.

Widhiarso, W. (2010). Uji Linieritas Hubungan. Diakses pada 31 Oktober 2019, dari http://www.widhiarso.staff.ugm.ac.i d/files/widhiarso 2010 uji lin ieritas hubungan.pdf. Stres Kerja terhadap Turnover Intention dengan Komitmen Organisasional sebagai Variabel Mediasi pada PT.PJB Services. Universitas Katolik Widya Mandala Surabaya. Jurnal Ilmiah Mahasiswa Manajemen (JUMMA), 6(2), 112-124

Yulianti. Riadi, Sukisno Selamet. Heksarini, Ariesta. (2019). Pengaruh Keadilan Sistem Kompensasi dan Komitmen Organisasi Terhadap Turnover Intention Pada Karyawan. Universitas Mulawarman. Jurnal Manajemen, 11(1), 1-8. 